\title{
Evaluation of the Usage of Open Data Portal in Banda Aceh Local Government in Indonesia
}

\author{
M. Zuhri ${ }^{1, *}$ Muhammad Afi Ramadhan ${ }^{2}$ \\ ${ }^{I}$ Department of Constitutional Law, Universitas Syiah Kuala, Indonesia \\ ${ }^{2}$ Department of Accounting, Universitas Syiah Kuala, Indonesia \\ *Corresponding author. Email: zuhri_mhd@yahoo.com
}

\begin{abstract}
This paper addresses issues on principle of openness and specifically, the open data as part of public information disclosure, open government, and e-government. As the founding member of the Open Government Partnership (OGP) since 2011, Indonesia is actively encouraging an open government practice and disseminate the idea not only to its surrounding countries, but also its own provincial area. As stated by Open Government Indonesia, there are several cities that currently become the pilot project area of open data implementation, including Banda Aceh, a city that was hardest hit by Tsunami in 2004. Its open data portal (data.bandaacehkota.go.id) provides datasets that were gathered and created by the corresponding units. This paper wants to evaluate the usage of open data portal in Banda Aceh, using literature review and evidence from Alexa web ranking system. The results showed that the website was visited by 2,776 unique visitors daily, but the website is considered as slow- loaded at 2.96 seconds. This issue needs to be addressed accordingly, because open data is the basic necessity needed to enable the smart city system, which the city is thriving to be at the moment. Based on the theories explained, in building the principle of transparency, the government has provided access to information by publishing various media of information that can be accessed directly by the public, the government has given a role to the community to be involved in governance and development. In conclusion, we recommend the government to encourage more people to use the open data portal and helping to trigger innovation for the city.
\end{abstract}

Keywords: Open Data Portal, Banda Aceh Local Government, Indonesia, Usage, e-Government.

\section{INTRODUCTION}

Good governance is a principle that must be implemented in governance, both central and local governments. Local governments have started to develop and apply several important principles or principles of good governance such as the principles of public interest, public participation, accountability and transparency.

The state of Indonesia is a state of law or Rechtstaat. One of the principles of Rechtstaat is transparency and social control [1]. The human rights content material in the amendment of the 1945 Constitution formulated in chapter X A, covers 10 aspects. One of them is human rights related to information and communication, specifically in
Article 28F [2]. This is a constitutional guarantee for public interest and participation, especially in helping to fulfil the good governance principle.

The application of general principles of good governance is also contained in Law Number 28 of 1999 concerning the Implementation of a State that is Clean and Free from Corruption, Collusion and Nepotism. Article 3 of the Law, in which one of them mentioned about the principle of openness [3].

In building the principle of transparency, the government has provided access to information by publishing various media of information that can be accessed directly by the public, the government has given a role to the community to be involved in governance and development. In implementing 
development, one of the strategies is the principle of openness. This is in accordance with the opinion of Jelantik (2017) [4].

Open government and e-government is one of the examples on implementation of principle of openness inside the government. This also resonates to smart city, where many governments are aspiring to become one. In this case, this paper aims to explore about the current implementation of open data as part of these afore mentioned initiatives. This paper addresses how to regulate the principle of openness in government administration, especially in governance in the city of Banda Aceh, and how to evaluate the use of data in the administration of government in the city of Banda Aceh.

\section{RESEARCH METHOD}

This research is a normative study using several problem approaches including the historical approach, the conceptual approach in analyzing the problem. The first research uses research on legal principles.

The analytical method used is qualitative normative. The method of analysis is carried out by interpreting and discussing research results based on legal principles, legal theories, legal definitions, legal norms and concepts related to the subject matter. To support the analysis, we use the result of Alexa web ranking analysis as the primary evidence for the reasoning.

\section{LITERATURE REVIEW}

\subsection{Public Information Disclosure}

According to the paradigm of good governance, the government is no longer merely relying on rules or government alone. However, it must also involve other elements such as the role of the private sector (private sector) and citizens (civil society) [5]. How the government is properly organized and managed is of course not only based on the principles of good governance, such as open government, accountability and legal certainty.

The public interest principle is believed by government administrators as the most dominant principle that has been applied by the government. This is because this principle is related to the main function of the government as the provider of public services. So, it is not surprising that most government programs and activities are then designed in the context of providing services to the community.

In some areas, the government's attention to the public interest was then complemented by opening up public complaints. This policy is intended as an effort so that the quality of services provided by the government to the community can be controlled and improved continuously. However, although this principle of public interest has become the main concern of government administrators, it does not mean that the quality of public services provided by the government has been on high performance [6]. Since accountability was established as one of the principles in government administration in 1998, accountability has become a very popular concept among government administrators.

Another form of accountability adopted by the government, particularly local governments, is performance reporting to the council and the public. Local government performance is reported to the council, and also to the public through the mass media. Such accountability is known as public accountability or external accountability.

The principle of transparency reflects the public's accessibility to information held by government administrators. Therefore, local governments that have tried to apply the principle of transparency have opened up opportunities for the public to be able to directly access various important information, such as policy designs, decision-making processes and mechanisms, and public service processes.

According to Law Number 14 of 2008 concerning Public Information Disclosure, public information disclosure is a must in an open government atmosphere to develop public information [7]. One of the mechanisms developed by local governments to create transparency in their regions is through the website. Although this mechanism has many limitations as an instrument of transparency, at least it shows the willingness of the regions to show the public about various matters regarding development programs in their regions.

Interestingly, since we are currently in the pandemic of COVID-19, we also need to adapt accordingly and looking back on how this public information disclosures were affected (or even impacting the mitigation process) in the pandemic. 
Gede Narayana, Chair of the Central Information Commission, explained that in handling the pandemic, Indonesia does not yet have a specific rule on information disclosure during a disaster. However, according to him, Indonesia can adhere to other articles, such as Article 7 paragraph (3) of the Law of Public Information Disclosure [8].

The government is obliged to provide and provide what is needed by the people. Therefore, they have the right to treat the provisions regarding the services provided, including the right to ownership of the facilities and infrastructure provided. On the other hand, for the people, obtaining good and satisfying and sufficient services is a right that is obtained by the people because of their status in terms of governance and moreover that right comes from the constitution [9].

The concept of governance is related to how governance is properly organized in accordance with the principles of good governance, such as: participation, rule of law, transparency, responsiveness and efficiency, and accountability, while the concept of government is related to issues structures or institutions that organize or implement governance.

\subsection{Open Government and e-Government}

Jauhar, et. Al (2015) argued that communication and information technology can improve good governance in three ways, namely first, increasing transparency, information, and accountability. Second, facilitate public participation in decision making. Third, improve the efficiency of public services [10]. Similarly, Sarofah, et. al. (2017) mentioned that changes and transformation are essential for a transparent and clean government so that they are responsive to change and easily understanding and applying new dynamics of public service towards e-Government [11].

Technology usually moves faster than legal systems. However, the technological revolution must always be pursued as a means to improve human life [12]. Advances in technology have brought rapid changes and shifts in a life without borders in this era of globalization [13].

In the era of globalization, the global communication network has become more and more integrated, so that the internet is increasingly popular and the world is getting smaller (Shrinking the world) [14]. Now, the internet offers more than two technologies (remote printing technology and satellite technology (real time)), so that information is updated [15].

According to Jimly Asshiddiqie, quoted by Wijaya, et. al. (2013), said that the positive impact of information technology is felt in the legal field, such as the effort to disseminate legislation through internet-based electronic media. Such a process of disseminating statutory regulations is called the promulgation of law [16].

As the founding member of the Open Government Partnership (OGP) since 2011, Indonesia is actively encouraging an open government practice and disseminate the idea not only to its surrounding countries, but also its own provincial area. As stated by Open Government Indonesia, there are several cities that currently become the pilot project area of open data implementation, including Banda Aceh, a city that was hardest hit by Tsunami in 2004. Its open data portal (data.bandaacehkota.go.id) provides datasets that were gathered and created by the corresponding units.

Kriyar, et. al. (2011) mentioned that there are several criteria that should be evaluated when building and evaluating e-government portals, namely: web presence, interaction, transaction, and participation [17]. This so-called "stage models" is important to see whether e-government (and all of portals within) are being utilized by the citizens. As the author mentioned, the further aim of the egovernment is to increase the say of the citizens by involving them in political transparencies. However, under our opinion, we say that this open data portal of Banda Aceh could still be considered as interaction (the second phase of the model), as it involved interactions of downloading the data from government to society.

\section{RESULTS AND DISCUSSIONS}

Banda Aceh is the capital city of Aceh Province, located on the western-most part of Indonesia. With a total area of $61.36 \mathrm{~km} 2$ and total population of 265,114 living on 9 sub-district and 90 villages (kelurahan), most of its citizens are Muslims (97.09\%), while the rest is minority from other religions. Banda Aceh gained a highlight for being 
the worst city hit by Tsunami Aceh in 2004 that devastate the whole city and its population; the number of populations in Banda Aceh decreased by a quarter in 2005 compared to 2004.

To evaluate the usage of open data portal in Banda Aceh, the author decided to use Alexa Rank as a fixed criterion to compare the performance of the website. Alexa rank is an important indicator for comparing websites with other sites, Alexa allows someone to compare websites to get detailed comparison in the chart. Alexa rank can provide information about website ranking traffic, the traffic data is taken through the Alexa toolbar on the visitor's browser of the website or blog. Every website or blog has a different Alexa rank. If a website or blog has a low website ranking, the better the rank, but if the Alexa website rank is high it means that the website traffic is low. Therefore Alexa Rank can be interpreted as a tool to see the ranking of a website or blog based on traffic or the number of visitors given or made by alexa.com [18].

Rank on a website is very influential in the survival of the website, because the higher the rank of the website, it will convince other visitors to come to the website. To increase rank on the website, a strategy is needed to achieve the desired rank increase and activity on the website, activity often occurs with the use of an article that causes discussion such as comments, meaning that there are visitors who come to the website [18]. Some of the characteristics of Alexa are as follows:

1. The lower the Alexa ranking value of a website, it means that the more user visits to the website.

2. The ranking of a website is based on measurement of reach and pageviews. Reach is measured by looking at the number of global internet users who visit the site while Pageviews are the total number of Alexa users who request a site URL. Repeated URL requests from 1 user on the same day will be counted as a single pageview.

3. Bounce rate is calculated from how long visitors stay and browse the website.

4. Alexa calculation by default is based on 3 months, but also includes a 7 day and 1-month calculation view.

5. Can find out the speed level of the website, and compare it with the standard speed of a website [19].
The author will look into the Alexa rank of Banda Aceh open data website through https://ipsaya.com/alexarank.php, where they provide a more complete insight to the information compared to Alexa's official website, and the website's free version cannot show the insight from subdomain (in this case, we could only see the free insight from the main website, which is bandaacehkota.go.id).

Firstly, the global ranking of the website is 156,764 , while the reach ranking is at 161,231 . The load speed is 2.96 seconds, which is considered as "slow", which on the perspectives of the percentiles, $77 \%$ of sites are faster.

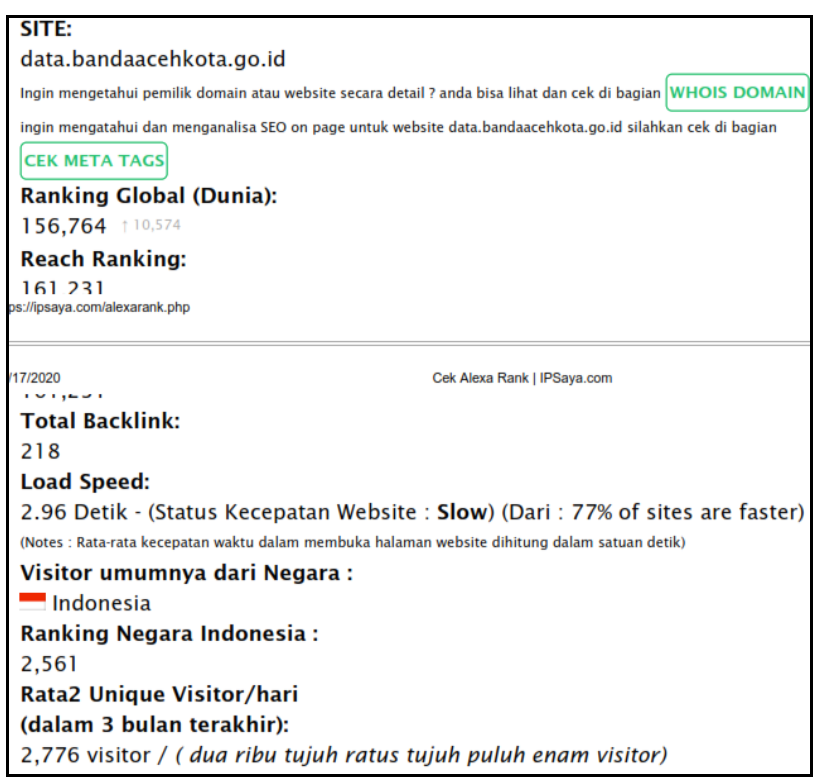

Fig.1. Result of Alexa web rank analysis (ipsaya.com, 2020)

This raise a red flag for the government of Banda Aceh, because in order to fulfil a good e-governance principle, local government should also think about maintaining the website for a better access. A slow website will discourage people from accessing the website and reaping the benefits of the website fully. We all should be reminded that digital inclusivity, digital adaptation goes beyond only "launching" the website and just ensuring that the government have a website. Government should also think on how to keep the website working on their best condition.

Continuing the data exploration, the Alexa rank detailed that the website of Banda Aceh open data is currently ranked at 2,561 nationally, and having an average daily unique visitor of 2.776 users for the 
past 3 months. On the larger note of change of ranking in the past year, the website had scored a good improvement, with the ranking goes up from around 240,000 to 156,764 at the moment. This means that the number of visitors had increased over the past 12 months.

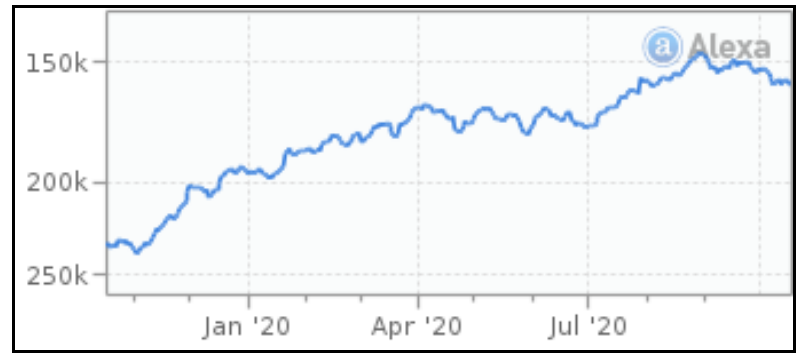

Fig.2. Traffic Graph of Banda Aceh Open Data Portal

(Alexa, 2020)

To give a rough comparison, Jakarta open data website is currently at 16,653 th of global ranking, with load speed of 1.121 seconds (considered as fast), and average of 15,486 unique visitors daily. Bandung open data website is currently at $56,808^{\text {th }}$ of global ranking, load speed of 1.177 seconds (also considered as fast), and average of 5,734 unique visitors daily. Taking examples from non-Java cities, Denpasar open data website is currently at $141,161^{\text {st }}$ of global ranking, with load speed of 0.96 seconds (also considered as fast), and average of 3,002 unique visitors daily. On the other hand, Pontianak open data website is currently at $275,853^{\text {rd }}$ of global ranking, with load speed of 0.871 seconds (considered as very fast), and average of 1,764 unique visitors daily.

Next, we investigate further into the presence and diversity of the datasets. Banda Aceh local government consisted of several "regional work units" (Satuan Kerja Perangkat Daerah - SKPD) that are handling specialized matters, such as health office, transportation office, hospitals, tourism office, and many more. Officially, according to Government Regulation Number 8 of 2006 concerning Financial Reporting and Performance of Government Agencies, SKPD is "an organization / institution in the regional government that is accountable to the governor / regent / mayor in the context of administering governance consisting of regional secretaries, regional offices and regional technical institutions, districts, and civil service police units according to regional needs."
Banda Aceh has a total of 46 SKPK (because Banda Aceh is a city, so it is called Satuan Kerja Perangkat Kota - SKPK), which consisted of 2 secretariats, 6 agencies (badan), 21 department offices (dinas), 3 offices / kantor (consisted of PDAM Tirta Daroy for water services, RSU Meuraxa for general hospital, and Satpol PP dan WH for sharia and civil service police service), 9 sub-districts, and 5 other work units. Impressively, all of these 46 SKPK have their full presence in the open data portal since August 2017, which means a very good marks and achievements for Banda Aceh local government which had managed to include all their working units inside the portal. Out of these 46 SKPK, the top 5 work unit with the most dataset published are: Health Office (37 datasets); Dayah Education Office (30 datasets); Transportation Office (22 datasets); Communication and Informatics Office (20 datasets); and Education and Culture Office (19 datasets).

Currently, the portal has 302 datasets and 434 data sources categorized into 17 categories, which are: Economics/Finance, Energy, Industry, Infrastructure, Islam, Disaster, Demography, Health, Environment, Maritime, Tourism, Education, Housing, Bureaucracy Reforms, Social, Technology, and Transportation. The 5 most viewed datasets are: Banda Aceh Online New Student Admissions - PPDB (20785 clicks); 2016 Regional Government Financial Report (4960 clicks); List of names of surgeons (3875 clicks); List of names of internists (3451 clicks); and Banda Aceh City River Data (2628 clicks).

We might have explored the width and depth of the spectrum, but we could not forget also to check the novelty of the data; this is really important so that citizens could be well-informed with the latest data, not the expiring one. Authors decided to evaluate this through seeing the 5 last updated datasets, 4 of them were in June $18^{\text {th }} 2020$, while the fifth is March $23^{\text {rd }}$ 2020. We realized that this might not be enough to judge whether the overall datasets were novel and could still be considered as relevant, but at the very least, we wanted to show that this indicator might show the effort of Banda Aceh local government to maintain the open data portal well-managed by updating and creating new datasets (if needed) regularly.

We can see that indeed open data was supposed to give so many benefits, but then, the question remaining here is whether the society at large as part 
of the local government itself are wary of the open data portal, and whether or not they are able to get the most out of it. This research is not covering about those awareness criteria, but at the very least, authors believed the idea of open data could trigger (and influence) larger public to participate and care about their own area.

Transparency is another critical point to be discussed when we raised issues about open data; it is, indeed, one of the most comprehensive (if not perfect) example of how the government should always uphold transparency on their governance. Availing datasets that are relevant for both the work of government and public means the government is being "frank and honest" about their status quo (or current condition) and therefore letting their citizens know about it, without any questions or doubts. Indeed, we need to acknowledge that there might be some super-confidential data that the government ought not to publish, but at the very least, we see this transparency as a good will (or even a "must" in this digital era) from the local government.

As argued by Sunindyo and Amrita (2019), not all the data that are collected by government could be published on the portal or website of open data. Government should not publish data which contains personal information of their citizens, and, in the context if a wider, national government, data which will trigger a danger for the security and the stability of the nation [20].

Interestingly, the intention and initiatives of creating an open data platform is not only coming from the government, but could also started by the people of the city itself, according to Fitriani, et. al. (2019). For instance, they mentioned on databases of election and data-driven journalism as the initiatives from the general public [21].

However, amidst all the fast-paced development of technology, government need also to realize on creating a policy for open data in which could ensure that governing body will keep being accountable and transparent by releasing their data [22]. This would be a good point for government which is currently on a more mature side, as they are already being experienced with managing and maintaining open data portal. But this doesn't mean that the newcomers- local government which just started their open data initiatives- cannot establish the policy and need to wait until they became more mature, but they can start formulating their own policy so that they can adapt with them in the near future.

Continuing on this issue, we see that the growth of open data portal around Indonesia, is a catalyst for local government (including Banda Aceh as the object of this research) to keep improving themselves and be better as time goes by. As stated by Rahmat (2019), local government, more important than ever, needs to engage more intensively with their own citizens, compared to the larger scale national government, thus urging them to have a better open data portal to spark more engagements, conversations, and actions [23].

Sometimes called as "peer pressure", this upward trend on numbers of local government launching their own open data portal, means a shifting from "good to have" values to "nice to have", especially when many cities in Indonesia are "racing" their way to be called as a smart city. And, as many had suggested, open data is one of the basic foundations for smart city.

Widiyastuti (2019) stated that strategic intent of local government on the implementation of smart city is fundamental and essential to advance the plan into reality, where the author argued that the initiative of smart city should be coming from a changemaking leader that encourages innovation and solution [24].

Sanjaya, et. al. (2018) argued that smart city discussion will always involve with the dynamic relationship of the government and the public, with relation to the information, technology, and, of course, data. Technologies related to smart city includes big data, e-government, the Internet, and digital infrastructures [25].

\section{CONCLUSION}

Open data, as a fundamental for smart city, had become a "new normal" for local government around the nation. This initiative goes in line with public information disclosure, which is one of a pillar for achieving good governance. This is truer in the current digital era, where e-government could help local government fulfilling this principle.

On the results of evaluating the open data portal, we recommend the local government of Banda Aceh to improve the loading speed of the website, as the 
test results showed and discussed on this paper. We also recommend the government to encourage their work units (SKPK) to upload more datasets to enrich the open data portal, and keeping the relevance of its datasets. As on the demand side, we also would like to advise the government to encourage more citizens to utilize the open data portal, so that the idea of open data is not only a one-sided supply only.

\section{REFERENCES}

[1] F. Laksono et al., "Status Keistimewaan Daerah Istimewa Yogyakarta dalam Bingkai Demokrasi Berdasarkan Undang-Undang Dasar 1945 (Studi Kasus Pengisian Jabatan Kepala Daerah dan Wakil Kepala Daerah)," J. Konstitusi, vol. 8, no. 6, pp. 1059-1086, May 2016, doi: 10.31078/JK\%X.

[2] I. D. G. Atmadja, Hukum Konstitusi, Problematika Konstitusi Indonesia Sesudah Perubahan UUD 1945. Setara Press, 2012.

[3] Republic of Indonesia, UU Nomor 28 Tahun 1999 Tentang Penyelenggaraan Negara Yang Bersih Dan Bebas Dari Korupsi, Kolusi, Dan Nepotisme. 1999.

[4] A. Jelantik, "Perekonomian Nasional dan Kesejahteraan Sosial berdasarkan UUD NRI Tahun 1945," J. Ketatanegaraan, vol. 006, p. 176, 2017.

[5] A. Ilmar, Hukum Tata Pemerintahan. Jakarta: Prenada Media Group, 2014.

[6] Lembaga Administrasi Negara, Penerapan Good Governance di Indonesia. Jakarta: Lembaga Administrasi Negara, 2007.

[7] N. Djumara, "Informasi Publik, Kearsipan dan Good Governance," J. Kapita Sel. Adm. Negara, vol. 1, no. 1, pp. 133-134, 2011.

[8] Open Government Indonesia, "Perspektif Keterbukaan Informasi Publik di Era Adaptasi Kebiasaan Baru," 2020. Accessed: Oct. 17, 2020. [Online]. Available: https://ogi.bappenas.go.id/admin/haloadmin/o ginews/Article_Keterbukaan_Informasi_Setn eg.pdf.

[9] F. Ali and N. Muhidin, Hukum Tata Pemerintahan Heteronom dan Otonom. Jakarta: PT. Refika Aditama, 2012.
[10] A. Jauhari, H. Basri, and M. Shabri, "Penerapan Good Governance Berbasis EGovernment dan Reformasi Birokrasi Dalam Rangka Meningkatkan Kinerja Satuan Kerja Pemerintah Aceh," J. Adm. Akunt. Progr. Pascasarj. Unsyiah, vol. 4, no. 3, Aug. 2015, Accessed: Oct. 18, 2020. [Online]. Available: http://jurnal.unsyiah.ac.id/JAA/article/view/4 479.

[11] R. Sarofah, "The Opportunities and Challenges of Makassar Government Towards Improving Services for Public Complaints Based on E-Government," J. Ilm. Wahana Bhakti Praja, vol. 7, no. 1, p. 13, Oct. 2017, doi: 10.33701/jiwbp.v7i1.72.

[12] L. Hardjaloka and V. M. Simarmata, "EVoting: Kebutuhan vs. Kesiapan (Menyongsong) E-Demokrasi," J. Konstitusi, vol. 8, no. 4, pp. 579-604, May 2016, doi: $10.31078 / \mathrm{JK} \% \mathrm{X}$.

[13] L. Hanim, "Pengaruh Perkembangan Teknologi Informasi Terhadap Keabsahan Perjanjian Dalam Perdagangan Secara Elektronik (E-Commerce) di Era Globalisasi," J. Din. Huk., vol. 11, no. Edsus, pp. 56-66, Mar. 2011, doi: 10.20884/1.jdh.2011.11.edsus.262.

[14] S. Arsyad, "Efektivitas UU ITE dalam Pengaturan Perdagangan Elektronik (ECommerce)," J. Huk. Bisnis, vol. 29, no. 1, p. 5, 2010.

[15] M. K. Wardaya and A. Komari, "Revolusi Media, Jurnalisme Global, dan Hukum Pers Indonesia," J. Din. Huk., vol. 11, no. 2, pp. 366-376, May 2011, doi: 10.20884/1.jdh.2011.11.2.194.

[16] E. Wijaya, R. Anggraeni, and D. R. Bachri, "Desa Digital: Peluang Untuk Mengoptimalkan Penyebarluasan Peraturan Perundang-undangan di Indonesia," J. Din. Huk., vol. 13, no. 1, pp. 75-88, Jan. 2013, doi: 10.20884/1.JDH.2013.13.1.158.

[17] E. Kriyar, "Assessment of e-government in Cambodia and Indonesia by web measure index and web usability," 2011, Accessed: Oct. 20, 2020. [Online]. Available: http://repository.ipb.ac.id/handle/123456789/ 
54437.

[18] U. Rahardja, Q. Aini, Y. Novita Dewi, D. STMIK Raharja, and M. STMIK Raharja, "Alexa Rank Sebagai Alat Ukur Popularitas Website Crowdfunding," Technomedia J. (TMJ, vol. 2, no. 2, pp. 29-40, 2018, doi: 10.5281/ZENODO.1325011.

[19] D. Novita and L. A. Fransen, "Analisis Popularitas Website Pemerintah Kota di Sumatera Selatan," in Seminar Nasional \& Konferensi Sistem Informasi, Informatika \& Komunikasi STIKOM Uyelindo Kupang 2017, 2017, pp. 414-419.

[20] W. D. Sunindyo and I. D. P. D. K. Amrita, "The Development of Data Publishing Tool for Indonesian Open Government Data," in Proceedings of the International Conference on Electrical Engineering and Informatics, Jul. 2019, vol. 2019-July, pp. 30-34, doi: 10.1109/ICEEI47359.2019.8988891.

[21] W. Resti Fitriani, A. N. Hidayanto, P. I. Sandhyaduhita, B. Purwandari, and M. Kosandi, "Determinants of Continuance Intention to Use Open Data Website: An Insight from Indonesia," Pacific Asia $J$. Assoc. Inf. Syst., vol. 11, no. 2, pp. 96-120, Jun. 2019, doi: 10.17705/1pais.11205.

[22] R. P. Nugroho, "Comparing Open Data Policies and Their Implementation in Developed and Developing Countries," $J$. Penelit. dan Pengemb. Komun. dan Inform., vol. 4, no. 3, 2014.

[23] A. F. Rahmat, A. Nurmandi, D. S. K. Dewi, and S. Salahuddin, "Does the Government Effectively in Optimizing Open Data? Analysis 'Jago Data' in Yogyakarta Municipality," J. Gov., vol. 4, no. 2, Dec. 2019, doi: 10.31506/jog.v4i2.6751.

[24] I. Widiyastuti, ST., MT, "Tata Kelola Institusi, Teknologi, dan Manusia: Bagaimana Pemerintah Daerah Menangani Komponen Smart City (Institutional, Technology, and Human Governance: How Local Governments Manage the Smart City's Components)," J. IPTEKKOM J. Ilmu Pengetah. Teknol. Inf., vol. 21, no. 2, p. 93, Dec. 2019 , 10.33164/iptekkom.21.2.2019.93-108.

[25] A. Sanjaya, S. A. Krisna, and T. B. Mursito, "Research Trends of Smart City in Indonesia: Where Do We Go from Here?," Int. Conf. Educ. Soc. Sci., 2018, doi: 10.31227/osf.io/ge359. 